\title{
THE CHINESE HOUSE CHURCH MOVEMENT IN SOUTH AFRICA
}

Author:

Grant, $\mathrm{S}^{1}$

Niemandt, C.J.P ${ }^{1}$

\section{Affiliation:}

${ }^{1}$ Science of Religion and Missiology, University of Pretoria

\section{Correspondence to:} Grant, $\mathrm{S}^{1}$

Email:

srg1@global.co.za

Correspondence to: Niemandt, C.J.P

Email:

nelus.niemandt@up.ac.za

\section{Postal address:}

Private Bag X20, Hatfield, 0028, South Africa

Dates:

Published: 01 Des. 2015

How to cite this article: Grant, S. \& Niemandt, C.J.P., 2015, 'The Chinese House Church Movement in South Africa', KOERS - Bulletin for Christian Scholarship, 80(2). Available at: http:// dx.doi.org/10.19108/ koers.80.2.2225

\section{Copyright:}

(c) 2015. The Author(s).

Published under the

Creative Commons

Atribution License.
Die doel van hierdie navorsing is om die Chinese huiskerkbeweging in Suid-Afrika by wyse van akademiese ondersoek aan die orde te stel en ' $n$ inleidende bespreking te bied van hierdie belangrike gebeurtenis in sendingwetenskap. Hierdie navorsing behels van die heel eerste beskrywings en navorsing oor hierdie haas onbekende verskynsel. Die bespreking geskied aan die hand van Alan Hirsch se konsep van apostoliese impak en die sogenaamde 'Jesus People'-beweging, toegepas op Chinese huiskerke in China en Suid-Afrika. Die navorsing skets ' $n$ kort oorsig oor die kerk in China om sodoende konteks te skep vir die gebeure in Suid-Afrika. Die inleidende bespreking van die Chinese huiskerke geskied aan die hand van 'deelnemende waarneming.' Die navorsing vervolg met voorstelle vir die verdere ontwikkeling van die huiskerke in Suid-Afrika.

The purpose of the research is to provide an academic introduction to the Chinese House Church Movement in South Africa, and to give a brief description of the importance of this new missiological event - for, even though the presence of these churches is well known, little is known about the churches themselves. This research represents some of the very first explorations and missiological reflections on this phenomenon in South Africa. Therefore, in this article Alan Hirsch's idea of 'apostolic genius' and its connection to 'Jesus People' Movements and their impact is explored within the context of the Chinese church, both in mainland China and in South Africa. A brief history of the church in China is provided as background and context for an exploration of the Chinese House Church Movement in South Africa - through 'participant observation'. Consequently, suggestions are made as to ways in which one can more effectively assist already existing Chinese house churches, as well as with the establishment of more Chinese house churches. As this is a previously mostly 'unknown' and/or closed-off community, the research undertaken in this article is of great importance as an initial exploration and missiological reflection on this phenomenon. 


\section{INTRODUCTION}

The rapid expansion of Christianity should be of interest to any student of Christianity and Church History. This is especially true of the expansion of the Far Eastern Church, as it is by most accounts a spontaneous expansion (Grant 2013:6). The purpose of this research is to provide a missiological introduction to the Chinese House Church Movement in South Africa, and to give a brief description of the importance of this new missiological event - for, even though the presence of these churches is well known, little is known about the churches themselves. The object of this study is to understand the potential for a 'Jesus People' Movement among the Chinese in South Africa (Grant 2013:6). In this research, Hirsch's (2006) work on 'apostolic genius' - specifically his six elements of 'apostolic genius' (Hirsch 2006:78-79) - will serve as dialogue partner, assisting the researchers' understanding and classification of the Chinese House Church Movement (Grant 2013:4). The researcher will answer the research question: Is the 'Jesus People' phenomenon of the Chinese House Church Movement in China being reproduced in the Chinese house churches of South Africa?

Further context is given to the South African Chinese House Church Movement in two ways: 1) by exploring it against the background of the explosion of Christian churches in China, and 2) by giving a brief history of Christianity in China. The research has established the following (Grant 2013:5): there is a large diaspora community of Chinese living in South Africa (over 350 ooo); this community is diverse and spread out all over the country, but does have a higher population concentration in Gauteng; the community is mainly made up of Chinese from mainland China; and there are, in fact, Chinese Christian churches within this community (few and small, but vital). It is to these churches that this paper is dedicated.

\section{METHODOLOGY}

This article is based on research done by Steve Grant (2013:10-12) (under the supervision of prof. Nelus Niemandt) as a 'participant observer'. The researcher was a participant-observer, as a unique set of circumstances allowed the researcher to gain a greater understanding of the Chinese House Church Movement in South Africa. The researcher participated in the planting of a Chinese house church in the West Rand of Gauteng, with the help of a Chinese businesswoman. The church was mostly composed of Chinese businesspeople from the Shanghai area. Though the researcher was the official 'pastor' of the church, he kept a very low leadership profile, due to a lack of fluency in Mandarin, as well as the desire to see what Chinese leadership would arise if his leadership presence was minimal. Although the researcher was thus not really involved in the leadership of the church, his involvement did mean extensive interaction with the Chinese participants of the church, and meetings with many church leaders. During this time he was also introduced to a Chinese Brethren Church in the West Rand. The Chinese Brethren Church of the West Rand was used as a case study.
This allowed the researcher the opportunity to conduct a qualitative study of this phenomenon by way of participant observation - the collection of data by observing participants, or directly asking them open-ended questions in multiple interviews (Creswell 2015:4).

The focus of the study on the Chinese House Church Movement in South Africa necessitated a broader description of the Chinese population in South Africa, through both literature and interviews conducted with pastors, missionaries, and Christian laymen. Through his involvement with his own, as well as this Brethren Church, the researcher came to know the history of the church in mainland China, specifically the Chinese House Church Movement, and the strong influence its traditions and prominent leaders (e.g. Watchman Nee) have had on the identity of the Chinese House Church Movement in South Africa (Grant 2013:5). As part of this research the history of the church movement in China, specifically the growth of the Chinese church from a struggling movement to a vibrant 'Jesus People' Movement, was done using literature study.

\section{The DNA of a 'Jesus People' Movement}

According to Hirsch (2006) in The Forgotten Ways, there are six elements that make up missional DNA $\left(\mathrm{mDNA}^{1}\right)$, and every church has this mDNA - the difference between churches

being that it can be fully expressed or partially expressed. The six elements are: 1) Jesus is Lord, 2) discipleship and disciple-making, 3) the missional-incarnational impulse, 4) an

apostolic environment, 5) organic systems, and 6) communitas. These six elements, when fully expressed, add up to what Hirsch (2006:78-79) refers to as 'apostolic genius', and leads to a 'Jesus People' Movement. A 'Jesus People' Movement is a spontaneous movement of a people group to Christ (Hirsch 2006:19-20). The mDNA serves as the reference point of the church, '...the life force that pulsated through the New Testament church and in other expressions of apostolic Jesus movements...' (Hirsch 2006:77).

The business of the church should be people and their lives, not buildings and/or programmes. Jesus made disciples and instructed his disciples to do the same. Growing in faith and achieving your God-given potential is essential, but can only happen when we keep our focus on the centrality of the missional aspect of God's programme, i.e. making disciples of Jesus. For it is only as we express the essence of the missio Dei in our church movements that we can truly be the church. God is the God of mission (missio Dei), it is essential to his very being (missio Trinitatis). For this reason, we - as followers of God - are also essentially missional/sent. This missional impulse is what motivates the church to participate in God's

1 Hirsch (2006:24-25) uses the abbreviation mDNA in his works as a summary of core characteristics of the missional church. He says it is a simple, intrinsic, reproducable, central guiding mechanism. It recognises the organic nature of the church and the conviction that the church participates in God's mission and is thus missional in its core (DNA) (Hirsch 2006:76). For a critique of Hirsch, see Van Gelder and Zscheile (2011:79). 
mission... We are missional as a church, as Guder (1998:5) says, when we are sending people out. The church should always be sending people out into the world, incarnating the life of Jesus. 'The church is called to be a dynamic movement rather than a static institution' (Hirsch 2006:155). Such an apostolic mindset and environment do not limit the growth of the church, but enhances it as it directs the flow of information for optimal growth, using the empowerment of apostles, prophets, evangelists, pastors, and teachers (Hirsch 2006:158). This process of empowering the different types of individuals in any new church needs to be accompanied by an organic system - that can change according to the need - in order to be as effective as possible.

The question should always be: 'What is the most effective way of doing things?' For information brings change, and there is always a constant influx of information (Hirsch 2006:183). So a system that does not have the ability to allow for fast movement and change will not do. Instead, a system that functions on the principle of communitas is needed - the common pursuit of a vision or mission - is able to move fast, as it is a system made up of people who are wholly committed, people who have personally experienced the mission, people whose previous state of disorientation has lead them into camaraderie (Hirsch 2006:221). Communitas is all about pushing to the edges, where there are no rules and safety is not assured. This is what the 'Jesus People' Movement should be all about; and a loss of any and/or all of these elements leads to a diminution of the life force of an authentic Christian Movement (Hirsch 2006:222). Hirsch's understanding of a Jesus People Movement can thus be seen in his definition of the missional church as 'a community of God's people that defines itself, and organizes its life around its real purpose of being an agent of God's mission to the world' (Hirsch 2006:82)

\section{A proud tradition: Christianity in China}

In order to be able to understand the potential for a 'Jesus People' Movement in Africa among the Chinese, we must understand the context of the movement as it arose in China (Grant 2013:9). The origin and character of the events in China are of the utmost importance in order to be able to understand whether a 'Jesus People' Movement is taking place in Africa among the Chinese.

It is also important, at this junction, to remember that Christianity is not new to China - on a stele in the city of Changan is a representation of a delegation of Nestorian Christians dressed in white robes arriving in the city in 635 C.E., the start of a Christian presence in China (see Aikman 2003:2122; Hattaway 2003:4; and Chan 2010:1). On several occasions, various popes sent monk delegates to the Mongols who ruled China (see Aikman 2003:28; and Jenkins 2008:14-15). Even Marco Polo, in 1266 C.E., had two Dominican monks with him on his trip to China (Aikman 2003:28). Polo brought back a message for the Pope from Kublai Kahn that, if he would send 100 missionaries to China, then he and his potentates would become Catholic (Aikman 2003:28). In response, the Pope only sent one missionary. In the 1500 s the Jesuits accompanied Francis Xavier to the Far East, and because of this, Mateo Ricci, who would later become an important member of the scholars in Peking and would have a profound effect on the Chinese court, landed in Macau in 1582 (Aikman 2003:31). The Jesuits would be expelled in 1722 (Lyall 2001:50).

Protestant missions to the Far East started in the 19th Century, together with Western colonial expansion (Chan 2010:1). Chief among the Protestants' mission efforts was the work of J. Hudson Taylor and the China Inland Mission (CIM) - Taylor would come to personify what would become an indigenous expression of the Chinese church (Aikman 2003:39; and Taylor 2003:59).

This served as the beginning to a long traditional church planting programme that continued into the middle of the 2oth Century; giving birth to such men as Wang Ming-Dao, Watchman Nee, and David Yang, who would lead the church through the persecution it suffered when the 'Bamboo Curtain' came down in 1950 (Hattaway 2003:13). 1949 was a time of massive transition and confusion in China the Communist Movement gained and seized power in mainland China (Aikman 2003:44), forcing Chiang Kai-Shek and the Nationalist Movement to flee to the island of Taiwan. Thismeant, inpractice, theend offreedom of religious expression in mainland China; since the Communist government required all foreign missionaries to leave the country (Aikman 2003:44). By 1953 the CIM had removed all their foreign missionaries from China (Thompson 1978:183). In the 1950s the government created the Three Self Patriot Front, which was to become the official state church, and was controlled by the government. All existing churches and religious groups were pressured to join. Churches were closed, properties seized, all printed material and books were burnt, and all the leaders sent to 're-education camps'. This meant that the church now found itself leaderless and without plans and programmes.

One positive effect was that the Chinese church now became truly Chinese, as persecution brought unity (Grant 2013:51), with the appearance of leaders such as Brother Yun, Peter Xu Yongze, and Enoch Wang. These leaders would lead the church into the 21st Century. This resulted in the development of two churches - the underground church and the Three Self Front church. The underground church was forced to go back to the Bible, simplify their understanding of church, and streamline its operation. They formed a church that affirmed all believers, a church where all the 'extraneous' things were put aside and simply living the words of Jesus became the norm. So what emerged was a full blown 'Jesus People' Movement - i.e. a spontaneous movement of a people group to Christ, which grew from modest beginnings to over a hundred million believers in China today (Hattaway 2003:13). One of the most amazing developments in this time has been the creation of the 'Back to Jerusalem' Movement (Hattaway 2003:23), a movement in which church leaders were inspired by the Holy Spirit to take the gospel where it had never been before. The logic ran like this: since the gospel came to us (Chinese) from Jerusalem, we are obligated to take the gospel to every nation between here and Jerusalem. We are obligated to take the gospel back to Jerusalem. And so began a huge mission movement that continues to this day. 


\section{A brief history of the Chinese population of South Africa}

In 1660, the ship "Arnhem" arrived in Cape Town from Batavia; aboard was a Chinese convict named 'Wancho' (Yap \& Man 1996:6; and Accone 2006:261). This marked the first recorded Chinese in South Africa. Today there are about 300 ooo Chinese in South Africa ${ }^{2}$ (see Park 2008:1; and Huynh, Park \& Chen 2010:289), consisting of three major groupings (Accone 2006:257): the South African-Born Chinese, who are descendants of the 19th Century Cantonese settlers; the Taiwanese from the Republic of China; and the latest grouping from the People's Republic of China (PRC).

The first major grouping of Chinese arrived concurrent with the South African Gold Rush in 1886. They were from the Southern Chinese province of Guangdong, and were Cantonese or Hakka (Harris 2013:179). There were estimated to be over 1000 individuals - who are not to be confused with the 63659 indentured labourers brought over by the British to work in the gold mines (Accone \& Harris 2008:189), as these labourers were repatriated to China. These early Cantonese formed the heart of the Chinese community in South Africa, with two major language groups forming in the community - the Moiyean from Northeast Guangdong who spoke Hakka, and the Cantonese who spoke Cantonese (Park 2008:15). The Cantonese settled in the Transvaal, while the Hakka speakers settled on the coast in places like Port Elizabeth (Park 2008:17). For the sake of brevity I will refer to them as the Cantonese. This group, of about 10 ooo members, now has second, third, and fourth generations of descendants (Huynh et al. 2010:289), who form the South African Born Chinese. The Taiwanese arrived in South Africa

in the late 1970s, when the South African government was looking to increase their industry in rural areas. They made enticing offers to Taiwanese industrialists, with government incentives which included, among others, relocation costs, subsidized wages for seven years, subsidized rent for ten years, cheap transport of goods to urban areas, housing loans, and favourable exchange rates to encourage the immigration of investors (Huynh et al. 2010:291). By 1988, 2500 immigrants from Taiwan had already responded to this invitation, with 150 factories built by 1989 and 300 by 1992 (Huynh et al. 2010:289-291). But interestingly enough, their numbers have been steadily decreasing, to about 6000 members today (Huynh et al. 2010:289). Deng Xiaoping came to power in the PRC in 1978; and, under his leadership, came the 'opening up' of China in 1993 - one of the contributing factors being the loosening of overseas immigration laws by the signing of the declaration of 'The Regulation concerning Chinese Citizens Going Abroad and Returning' (Huynh et al. 2010:292) in 1985. Immigration had now become legal, which led to a flood of people leaving China. The diaspora had begun. In the late 1990s, the largest segment of the Chinese community - estimated at between 200 ooo to over 350000 people (Huynh et al. 2010:289) - began arriving in South Africa. These people come from the Fujian province in Southern China, and

$2 \quad$ The official South African census covers all Chinese under the category of 'Indian/Asian'. are mostly small shop owners and peasants. The vast majority of them are illegal immigrants arriving in South Africa through Swaziland or Lesotho who, once in the country, live and work with family.

\section{The Chinese Church in South Africa}

Important to note at the beginning of this section of the article is the fact that there is a lack of literature on this issue, and that no formal statistics are available. The following is thus based on observations and interviews done by the researcher (Grant 2013:81-98). The researcher began with involvement and context analysis, which took the form of interviews and participant observation. This included observation to gain better understanding of Chinese Christians in South Africa.

Estimates on the Chinese population in South Africa vary between 350000 to 500 ooo people. There are about 15 Chinese churches in South Africa, with a Chinese church averaging about 30 people per congregation. This means that the Chinese church is reaching approximately $0.13 \%$ of the overall Chinese population, which leaves a very large area for growth. In the Chinese churches in existence, many denominations are represented - from the Methodist, Reformed, Presbyterian, Baptist, Brethren, Covenant, Pentecostal, and Bible churches, to Mission and Independent Non-denominational churches.

Now, after having carefully studied the church in China, one could have initially worked from the expectation of seeing the same rapid growth that the Chinese church experienced replicated in the Chinese churches of South Africa. This research has found that the growth of the Chinese South African Church is not rapid but moderate, as the receptivity of South African Chinese is much lower than that of mainland Chinese (Grant 2013:97). The most commonly reported reason for this is that the Chinese entrepreneur has come to South Africa to make money. Thus business is their major occupation, with consequently the contemplation of religion not being a major preoccupation (according to Pastor B. Sia, interviewed on 10 May 2004; and Pastor D. Hughes, interviewed on 20 May 2004). The lure of Western materialism is very strong, and the opulence of the society is very appealing. A person can have amuchmorecomfortablelifeinSouthAfricathantheywouldhave had in China. Yet the South African social context is extremely different from that in China, and the Chinese are newcomers to this culture, not yet disenchanted with its philosophies and dreams. In this vastly different Western context Christianity is seen as a 'Western phenomenon', rather than something that is available to them. Also of importance here is that the leadership of the Chinese churches in South Africa are not from mainland China, but rather from other places (particularly Taiwan). As such their growth is much more indicative of the Taiwanese church - i.e. moderate growth. Pastors involved with Chinese churches have also reported on the impact made by the fact that the South African Chinese culture is not a literary culture - getting them to read the Bible does not work, whereas having conversations or relating stories is a much more effective way of conveying truth to them. This is especially problematic as most Western programmes do not fit into this category (according to e.g. Pastor B. Sia, interviewed on 5 June 2013). Also, most pastors 
are busy helping non-believers with their daily problems rather than leading Bible studies.

The scale of Chinese migration to South Africa, the fact that there are very few Chinese churches and very little information on the integration of Chinese Christians into existing mainline churches, poses a number of challenges:

One of the major challenges is the lack of adequate translation of the Bible and other religious works into Mandarin, or concerted efforts to teach the Chinese in South Africa to use the English language (Grant 2013:84). Another aspect of Christian ministry that warrants deeper investigation is the possibility of finding Chinese Christian social workers who can start with the development of contextually appropriate social programs (Grant 2013:90, 109, 116)

There is a great need for contextually appropriate leadership training programs (according to e.g. Pastor B. Sia, interviewed on 5 June 2013),-i.e. local internships and training programmes are needed, with youth programmes (e.g. 'A Year of your Life' programmes) being a key example (according to, for example, Pastor M.C.S. Liu, interviewed on 19 December 2012).

Then there is also the challenge of intentional church planting, as there are entire communities without even a single Chinese church in them. Keeping in mind the setup and functioning of a typical Chinese house church - as explained above - then that would mean that a population of 350 ooo Chinese in Gauteng theoretically implies room for 350 Chinese house churches (one church for every thousand non-believers, Montgomery 1989:47). This is what we call a 'Saturation' Church Planting Movement (CPM). Such a movement can only come about when all the different churches that make up the church as a whole embrace the call to reach all the people and start working together within their area (Grant 2013:108-111, and Montgomery 1989:11-12).

\section{Missions and the South African Chinese Church}

Interest in the Chinese situation in South Africa has been shown by both English and Afrikaans-speaking churches, as well as different missionary organisations. Because of this interest the Southern African Chinese Outreach Network (SACON) was brought into existence (according to K. Teichert, interim Chair for the Gauteng group of SACON, interviewed on 16 May 2013) - they coordinate with the Overseas Missionary Fellowship (OMF) to present training seminars for local churches who are interested in how to reach out to the South African Chinese population. The seminars offer a specialised view on understanding Chinese culture and world view, as well as practical ways to reach out to them. OMF's vision is for a prayer movement for the Chinese diaspora, for pastors and/ or missionaries from China - specifically trained to minister to the Chinese in Africa, for ministry by local churches to Chinese churches, and for support of Christians returning to China. This has become a joint outreach between the Chinese churches and the English/Afrikaans churches, with branches in Gauteng, Cape Town, Gaborone, Harare, and Nairobi.
This outreach needs to be supplemented by local churches setting goals to plant new and/or other churches; for the planting of new churches is the best evangelistic method (Montgomery 1989:38), as new churches are dynamic entities, which bring with them a certain amount of excitement. Usually, lay involvement is also very important in these new churches (see e.g. Gibbs 2005:21, Frost \& Hirsch 2003:166-169, and Grant 2013:21-34). A church that does not plant new churches becomes stagnant; which implies then that the daughter church itself must also have within its nature the drive to plant churches.

\section{Moving forward}

Through the above it has become clear that the six elements of 'apostolic genius' (Hirsch 2006:78-79) in their totality are not readily evident in the Chinese church in South Africa. This means that, although the Chinese church in South Africa is growing, it is not growing in the way a 'Jesus People' Movement should/would (i.e. explosive growth). Nevertheless, the necessary conditions are there for explosive growth to be a real possibility (Grant 2013:106), as the Chinese are very open to the gospel, receiving the Word without opposition when it is offered. Yet, in order for explosive growth to not only be a theory but something taking shape in reality, several things are needed (Grant 2013: 105, 114-116):

Chinese pastors have to come together in their struggle with the issues of their various communities, since they are all in actual fact facing the same things - too many non-evangelised Chinese people, not enough workers. For this to be effective contact with, and a growth in trust of, one another is essential. But, even if all these pastors were to come together, they still will not be able to do it on their own - the sheer number of Chinese people to be reached is just too overwhelming.

A directory of all the Chinese churches has to be compiled, so that every church has a list of all the other churches working with the same people-group as they are. Such a directory would also mean that, when a member moves, he/she can be directed to a church in the area they are moving to.

A more detailed study of the existing Chinese churches will also help immensely with contextualisation and practical implementation - when those from outside the Chinese churches want to start helping.

The planting of new churches must be considered and conceptualised. As has been stated earlier, there is room for 350 Chinese house churches in South Africa. With 15 churches currently in existence, there is a long way to go. A Church Planting Movement must be started - for with such a movement in action it is possible for a church to plant another church every 2 to 3 years, which would double the number of Chinese house churches.

The issues of crime and corruption must be discussed and faced, for every church member faces this issue in more than one way. It is the biggest problem facing the Chinese Church in South Africa-. 
Leadership must be discussed. Does one need a 5 year seminary degree to lead a church of 30 people? Can in-house training replace expensive overseas training? What age does a leader have to be to start leading? How does God choose a leader? Does education make a leader? Or is it rather practical experience? Where will all the new leaders come from? How do you keep growing as a leader? What about leader fall-out?

Appeals must be made to the church in mainland China to share what they have with the churches in South Africa, since there is already such a vibrant 'Jesus People' Movement in China. A team of Chinese missionaries, with the right training, could make quite an impact on the South African resident Chinese population. Of course there will be culture shock and massive changes, but thousands could potentially come to Christ. By taking hands/partnering with the church in mainland China, the missional efforts amongst the Chinese in South Africa can be greatly helped.

\section{CONCLUSION}

By becoming a 'participant observer' within the Chinese House Church Movement in South Africa, Grant was able to engage with, and do research within, a previously quite 'unknown' and closed-off population group. A population group that is only growing in numbers. This research not only provides more context and understanding for the Chinese population as a community and as a group of believers, but can also aid the wider church in reaching this 'hidden' group of people. With the right approach the number of Chinese churches, and their reach and/or influence on the Chinese population of South Africa, could be doubled (even tripled) in a very short time. Especially if those churches reaching out to the Chinese, and the Chinese churches already in existence, were to tap into the inherent power of 'apostolic genius'; for, when fully expressed, this is a powerful force for the growth of the Christian faith and the planting of new churches.

\section{BIBLIOGRAPHY}

Accone, D., 2006, 'Ghost people': Localising the Chinese self in an African context, Asian Studies Review, September: 257-272.

Accone, D. \& Harris, K.L. 2008, A century of not belonging: the Chinese in South Africa (In Kuah-Pierce, K.E. \& Davidson, A.P. (eds.), At home in the Chinese diaspora: Memories, identities and belongings, Palgrave Macmillan, New York, pp. 187-205.

Aikman, D., 2003, Jesus in Beijing, Regenery Publishing, Washington.

Chan, K.K., 2010, Mission movement of the Christian community in mainland China: Back to Jerusalem Movement, Seoul Consultation Study Commission, Edinburgh. http://www.edinburgh2010.org/fileadmin/files/edinburgh2010/ files/pdf/Kim-Kwong\%20Chan\%202009-2-28.pdf Date of access: 20 Feb. 2014.

Creswell, J.W., 2015, A concise introduction to Mixed Methods Research, SAGE, Thousand Oaks.

Frost, M. \& Hirsch, A., 2003, The shaping of things to come: Innovation and mission for the 21 century church, Hendrickson Publishers, Peabody.

Gibbs, E., 2005, Leadership next, Intervarsity Press, Downers Grove.

Grant, S.R., 2013, A missiological perspective on a South African Chinese House Church in the light of Alan Hirsch's six elements of 'apostolic genius', MA dissertation, Science of Religion and Missiology Department, University of Pretoria.

Guder, D., 1998, Missional church, Eerdmans Publishing, Grand Rapids.

Harris, K.L., 2013, The Chinese in South Africa: Five centuries, five trajectories (In Chee-Beng, T. (ed.), Routledge Handbook of the Chinese Diaspora, Routledge, New York, pp. 176-190).

Hattaway, P., 2003, Back to Jerusalem: Three Chinese House Church leaders share their vision to complete the Great Commission, Authentic Publishing, Tyrone.

Hirsch, A. 2006, The forgotten ways: Reactivating the missional church, Baker Publishing, Grand Rapids.

Huynh, T.T., Park, Y.J. \& Chen, A.Y., 2010, Faces of China: New Chinese migrants in South Africa, 1980s to Present, African and Asian Studies 9: 286-306.

Jenkins, P., 2008, The lost history of Christianity, Harper-Collins, New York.

Lyall, L., 2001, Three of China's mighty men, OMF International, Kent.

Montgomery, J., 1989, DAWN 2000: 7 million churches to go, William Carey, Pasadena.

Park, Y.J., 2008, A matter of honour: Being Chinese in South Africa, Jacana, Auckland Park.

Taylor, J.H., 2003, Looking back, OMF International, Littleton.

Thompson, P., 1978, China: The reluctant exodus, Davidson Publishing LLC, Littleton.

Van Gelder, C.A. \& Zschweile, D.J., 2011, The missional church in perspective. Mapping trends and shaping the conversation, Baker Academic, Grand Rapids.

Yap, M. \& Man, D.L., 1996, Colour, confusion and concessions: The history of the Chinese in South Africa, Hong Kong University Press, Hong Kong. 